JBSED

1,1

102

Received 29 January 2021

Revised 15 March 2021

Accepted 17 April 2021

\section{Determinants of the performance of Moroccan banks}

\author{
Abdelkader Derbali \\ Department of Finance and Accounting, \\ Universite de Kairouan Institut Superieur d'Informatique et de Gestion de Kairouan, \\ Kairouan, Tunisia and \\ Department of Administrative and Financial Sciences and Techniques, \\ Community College, Taibah University, Al MAdinah, Saudi Arabia
}

\begin{abstract}
Purpose - The economic and financial literature dealing with the subject of bank profitability has often been based in the measurement of banking results on three main indicators: ROA, ROE and MIN. This article aims to determine and analyze the different determinants that influence bank profitability and to identify the impact of these determinants on the profitability of Moroccan banks.

Design/methodology/approach - For this purpose, a fixed individual effect model was adopted for the case of six Moroccan banks during the period of study from 1997 to 2018. The authors carried out their estimates at three levels according to three categories of profitability factors: bank factors, factors of the banking system and macroeconomic factors.

Findings - The empirical findings show that Moroccan banks react on their size to boost their performance, which further explains the continued expansion of Moroccan banking networks. The authors confirm that Moroccan banks have not yet reached a level of size that will be detrimental to their performance. Therefore, the authors can conclude that the big Moroccan banks do not follow the concept of economy of scale. The effects of the variation in the level of economic growth as well as the evolution of the level of inflation on the performance of Moroccan banks are not significant.

Originality/value - The authors' findings and results have some important originality and value. Primarily, these results would consist of better helping the State, bankers, and bank managers to better understand the various determinants of bank profitability. The results may also help to better examine the effect of each factor, whether internal or external, on banks' bottom line.
\end{abstract}

Keywords Banking performance, ROA, ROE, MIN, Fixed effects model

Paper type Research paper

\section{Introduction}

These days, the financial world is changing with a rapid trend. Technological trends in the IT and telecommunications fields as well as the intense nature of international competition have brought about transformations and changes in the banking sector in many countries. At the heart of this increasingly complex and changing environment, faced with the diversity of products, and the expansion of markets, the Moroccan banking system, whose banks are to a considerable extent universalized, reorganized, computerized, diversified and currently in the

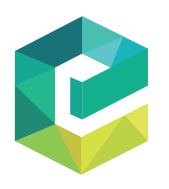

(C) Abdelkader Derbali. Published in Journal of Business and Socio-economic Development. Published by Emerald Publishing Limited. This article is published under the Creative Commons Attribution (CCBY 4.0) licence. Anyone may reproduce, distribute, translate and create derivative works of this article (for both commercial and non-commercial purposes), subject to full attribution to the original publication and authors. The full terms of this licence may be seen at http://creativecommons.org/licences/by/4.0/legalcode

The authors are grateful to the Editor and the anonymous referees of the journal for their extremely Journal of Business and Socioeconomic Development Vol. 1 No. 1, 2021 pp. 102-117

Emerald Publishing Limited e-ISSN: 2635-1692 p-ISSN: $2635-1374$
Funding: The author(s) received no financial support for the research, authorship and/or publication of this article.

Declaration of Conflicting Interests: The author(s) declared no potential conflicts of interest with respect to the research, authorship and/or publication of this article. 
process of internationalization thus giving right to firms that must now be observed and examined with a new perspective, has enjoyed considerable growth, and has marked a good contribution of support to the country's economy. In recent years, Moroccan banks have generally achieved satisfactory levels of solvency, considerable levels of profitability, and their management remains of high quality without neglecting the performance of their control system. This is due to a favorable economic situation, to the active support of the supervisory authorities, and to the market, which is well mastered, well managed, well controlled, and well protected.

In this context, the considerable profitability currently experienced by some Moroccan banks is likely to be threatened and called into question in the long term, especially with the double effect of customer pressure and the intensification of national, regional and international competition.

Banks as units of economic, social and societal development promote economic activity in various ways. Recent studies such as that carried out by Levine (1996) show that the efficiency of financial intermediaries can also influence economic growth.

While the study of the weight of several indicators on banking results has long occupied an important place in the economic and financial literature, a new light on the question remains necessary. In general, it becomes necessary to assimilate the consequences of variations in these indicators on the results of financial intermediaries in Morocco. The issue arousing our interest through this article is to know: what are the internal and external determinants of bank performance, and how these factors influence bank performance in Morocco?

To respond to this question, the objective of this article is to determine and to analyze the different determinants that influence bank performance and to identify the impact of these determinants on the performance of Moroccan banks. We employ a fixed individual effect models for the case of six Moroccan banks through the period of study from 1997 to 2018. Our assessments were conducted out at three stages corresponding to three classifications of performance factors: bank specific factors, banking system factors and macroeconomic factors. The empirical results of our paper demonstrate that size of bank present a significant impact on the performance of Moroccan banks. Consequently, the level of economic growth and the level of inflation does not affect the performance of Moroccan banks.

The rest of our study is organized as follows, Section 2 is devoted to the presentation of the elements of the theoretical and empirical literature review dealing with the determinants of bank profitability. Section 3 is devoted to present the methodology. Section 4 presents the data. Section 5 presents the model estimation. Section 6 presents the empirical findings.

\section{Literature review}

The economic and financial literature dealing with this subject is very rich. Several studies have focused on the determinants of bank profitability. Some works have focused on internal factors, others have analyzed in addition to internal factors, macroeconomic factors, and market factors. Most of these studies have focused on the cases of industrialized countries, but few studies have analyzed the profitability of banks in emerging countries, and particularly in Arab countries. Many models and techniques have been used in these different research (fixed or random effect models, parametric approaches, non-parametric approaches). The outcomes and conclusions are similar for some determinants, and contradictory for other variables. Regarding to Dermirguc Kunt and Huizinga (2000), this is explained by the divergence of elements of studies such as mainly: databases, the economic and regulatory environment, financial markets, and the statutes of banks.

In what follows, we present the results of some studies carried out in recent years in Western and Arab countries. Lanotta et al. (2007) study a sample of 181 banks belonging to 15 
JBSED

1,1

104

European Union countries for the period from 1999 to 2004. The objective of this research was to assess the effect of the ownership structure of banks on the profitability and risk. The authors end with the following conclusions: State banks are less profitable than private banks because of the quality of assets (credit risk) and liquidity risk, banks belonging to pension funds are less profitable faced with the risks relating to assets as private and state banks, there is no relationship between profitability and concentration of ownership.

Regarding to European banks, specifically for domestic banks, the analyzes of Pasiouras and Kosmidou (2007) show the existence of a positive relationship between the bank's profitability measured by the ROA (net income compared to total assets) and the following internal and external factors: capitalization, liquidity, GDP growth, inflation, market capitalization to total bank assets and the ratio of market capitalization to GDP. This study also indicates a negative relationship between profitability and the following variables: the size of the bank, the operating expenses compared to the result, the concentration of the banking sector and the total assets of the banks compared to the GDP.

Through a study on the internal and external determinants of profitability focusing on 3 banks in Greece observed over the period 1985-2001, Athanasoglou et al. (2006) produce the following results: the capitalization ratio (equity capital to total assets) and productivity (GNP compared to the workforce) have a positive effect on profitability (ROA and ROE); credit risk and the ratio of general operating expenses to total assets have a negative effect on bank profitability; as well as some determinants of bank size, ownership structure and concentration of the banking sector have no impact on profitability. The authors also concluded that the internal determinants that act positively on profitability measured by ROE can be summed up in three variables: capitalization, the size of the bank (total assets) and liquidity by inventing that the operational efficiency measured by the general and administrative expense ratio to total assets has a negative impact on profitability.

Like these results, there are authors among others who have come to other conclusions regarding certain variables cited above. Abreu and Mendes (2002), for example, have estimated that the profitability and the ratio of allocation of funds (or resources) measured by the loan/deposit ratio maintain a positive relationship, thus confirming the complementarity between credit policies and bank deposits. And concerning the size of the bank, by performing regressions on panel data and by expressing profits as a function of a group of internal and external determinants, certain authors (Bourke, 1989; Molyneux and Thornton, 1992) have led to a positive and statistically significant relationship between the size and profitability of assets. Other authors (see, e.g., Rouabah, 2006) however argue that size is not a source of cost savings, arguing that large banks face inefficiencies of scale. And relative to banking concentration and the size of the banking sector, their estimated effect on the profitability of banking assets is generally positive, which is empirically consistent with the economic theory of Ben Naceur (2003) and Rouabah (2006).

In addition, bank profitability always depends on a multitude of factors, both quantitative and qualitative. Many factors simultaneously contribute to the explanation of bank profitability. Even non-traditional banking activities can influence banking performance and efficiency (Ghouila and Jilani, 2019). Other factors related to the governance of banks and the way they are managed are also likely to have an impact on banking performance.

Estimating the effect of macroeconomic variables, including economic growth (GDP) and inflation, has often led to conflicting conclusions. Several authors unanimously confirm the existence of a positive relationship between economic growth and bank profitability (Bashir, 2000; Rouabah, 2006; Echekoba et al., 2018; Lawal et al., 2018; Panigrahi et al., 2019, Qureshi et al., 2019). Their opinion was, national wealth promotes all economic activity in the country, positively affects the development of the banking sector and encourages banks to innovate and renovate their management techniques and technologies. Regarding the impact of the variation in the general level of prices, the work of Molyneux and Thornthon (1992) and 
Abreu and Mendes (2002) shed light on the links that may exist between return on assets and inflation. Their empirical findings show a positive relationship which suggests that rising inflation will be favorable to growth in bank profitability.

\section{Methodology}

To provide answers to our initial problem, we opted for the empirical analysis of bank profitability for the Moroccan case, to do this we opted for the choice of a panel of Moroccan banks as a study sample. or the six Moroccan banks listed on the Casablanca Stock Exchange: Attijariwafabank (AWB), the Moroccan Foreign Trade Bank (BMCE Bank), the Banque Centrale Populaire (BCP), the Moroccan Bank for Commerce and Industry (BMCI), Crédit du Maroc (CDM) and Crédit Immobilier et Hôtelier (CIH).

Our objective is to test the implication of certain variables and determinants and to conclude as to the nature of their impact on the results of the banks studied. We also point out that the period that our study covers (1997-2018) went through the regulations and major liberalization reforms experienced by the Moroccan banking system and which obviously affects the entire economic and financial system of the country.

To empirically analyze the effects of the various factors of bank profitability, we have opted for an econometric approach which is that of panel data analysis techniques which combine both temporal and individual effects, which gives the possibility of increase the number of observations. To this end, we adopted the model with individual fixed effect for the sample formed and observed over a period from 1997 to 2018. In other words, to try to verify the impact of the various determinants of profitability banking, we proceeded to the collection of statistical data relating to the Moroccan banking institutions mentioned above and collected separately instead of working on the aggregated results of the country's banking system.

\subsection{Endogenous variables}

To measure bank profitability, three indicators are often used: ROA (Return on Assets), ROE (Return on Equity) and NIM (Net Interest Margin). We use all three measures in our analyses. In these following lines, we will detail what these three indicators clearly measure: The ROA represents the ratio of net income to total assets shown on the balance sheet. It therefore shows the ability of the bank to generate profit from its asset base. Since we divide the result by the assets, we therefore obtain, for one dirham of assets on the balance sheet, the gain that has been acquired. The higher this ratio, the more profitable the bank, since this means that with the same dirham of assets, it will be able to generate more profits. Although this ratio does not consider the so-called off-balance sheet assets, it is, as Golin (2001) points out, the most widely used profitability indicator.

$\mathrm{ROE}$ represents the ratio of net income to the amount of equity shown in the liability side of the balance sheet. It therefore represents the bank's ability to generate profit through contributions from its shareholders. It may seem very interesting to use ROE, taking into consideration that the higher the ROE, the more the bank manages to generate profit with one dirham invested, which therefore makes it a good indicator of profitability. Without prejudging that the $\mathrm{ROE}$ is a bad indicator of bank profitability, we consider with the authors Dietrich and Wanzenried (2011) that it has weaknesses which make it less attractive than the ROA. Indeed, while it is possible to interpret the ROE as the simple ratio of net income to equity, its decomposition into two ratios is also possible: the ROA multiplied by the ratio of assets to equity. So, let us look at this last ratio. It is usually called the bank multiple of equity and indicates the financial leverage of the bank: the more the multiple of equity is increasing, the more the financial leverage is also increasing, and vice versa. 
JBSED

1,1

From this, it follows that two banks with the same ROA (and therefore as profitable as the other according to this criterion) can have two different ROE ratios: the bank with the most important financial leverage will therefore have the highest ROE. higher. Likewise, two banks with different returns (measured by the ROA), can nevertheless have the same ROE. It is enough that their financial levers are different.

Since on the one hand the ROE does not consider the risk entailed by a high financial leverage and that on the other hand this financial leverage is often fixed by the regulations (in particular the regulations of Basel II then soon Basel III), we will attach more importance to the ROA in our future analyzes.

The MIN is a ratio that reflects the difference between the interest rate at which a bank lends and the interest rate at which it refinances in different capital markets. The interest margin should enable the bank to meet all its overheads and to generate sufficient profitability in relation to the capital tied up. To measure it, several ratios were used by researchers, for example the ratio of net interest income to productive assets, but through our study we used the ratio used by Mansouri and Afroukh (2006) net banking income compared to total assets.

\subsection{Exogenous variables}

The size of the bank: to measure the size of the bank, as in the case of most studies in this same sense, we have used the logarithm of the total assets of the bank (we are talking exactly about the natural logarithm). The question that will seem central to our study is what, in our opinion, will be the impact of size? Some authors highlight the economies of scale associated with a large size while others stress the difficulty of managing a very large bank, which leads to additional costs. In addition, the financial crisis is characterized by a crisis of confidence between banks, which refuse to lend in the short term (hence the intervention of central banks to inject liquidity into the financial system). It is therefore possible that small banks are less prone to liquidity cracks in the financial system and therefore have been able to withstand the crisis better than the large banks. This is of course only a hypothesis that we will verify in our analyses.

The capitalization ratio: to measure it, we will use the ratio of equity to total assets. It is also a measure of the bank's risk, since the lower this ratio, the less resources the bank has in the event of asset impairment. However, this is precisely what happened during the financial crisis: due to the contagion of subprimes and other extremely risky assets in the balance sheets of most of the banks of the financial systems which were indeed impacted by this crisis, the value of their assets fell sharply. As we saw during the theoretical part of the work, all the authors who were interested in the subject (Bourke, 1989; Berger, 1995; Demirgüç-Kunt and Huizinga, 1999; Abreu and Mendes, 2002; Goddard et al., 2004; Naceur and Goaied, 2001; Pasiouras and Kosmidou, 2007; García-Herrero et al., 2009; Liu and Wilson, 2010; Naceur and Omran, 2010; De Jonghe, 2010) have shown a positive effect of capitalization on bank profitability. Let us then wait for the confirmation of our analysis.

Liquidity: Like many authors, we measure liquidity, by calculating the ratio of loans to total assets. More precisely, we recall that this ratio is rather a measure of illiquidity, since the higher it is, the lower the bank's stock of liquidity. As we have seen, most authors believe that liquidity has a negative effect on bank profitability. They argue that low liquidity, that is, high liquidity risk, means larger margins to offset this risk. We do not yet know what we will get in our analyzes as a result, but the hypothesis that we formulate is that of a positive effect of liquidity on bank profitability.

Fund allocation ratio: This variable is an indication of the rate of transformation of deposits into loans and investments (securities), we used the ratio of loans to deposits for our analysis, as to the effect of this variable, we can expect it to be positive just as we can expect it to be negative. 
The average cost/income ratio: it represents the ratio of general operating expenses to net banking income; we expect a negative effect of this variable on bank profitability.

The size of the banking sector: it is measured by the logarithm of the total assets of the banking system, and for the case of our study we calculated the logarithm of the total assets of the six banks studied, according to the economic and financial literature we expect a negative effect of this variable on bank profitability.

The interbank rate: this corresponds to the interest rate applied to short-term transactions that banks make with each other. This rate is generally dependent on central bank rates, as well as future expectations. We obtained its evolution for the period studied from data from Bank Al-Maghrib.

Banking concentration: to measure banking concentration, we used the following ratio: total assets of major banks, i.e. (total assets of AWB, BCP and BMCE Bank) compared to the total assets of all the banks studied. We expect a positive effect on bank profitability.

GDP economic growth: we understand GDP growth is not a variable inherent in banks, but obviously a macroeconomic variable. However, we want to include it in our analysis, because we believe that it can have a significant impact on bank profitability. Indeed, in times of strong growth, consumption and investment pick up, so it is no coincidence that most studies include GDP growth as an independent variable. We advance the hypothesis that high GDP growth has a positive effect on bank profitability.

Inflation: it is possible that the general variation in price levels can have its effect on bank profitability, for this, we proceeded to integrate it in our analysis, we obtained the evolution of inflation for the period studied in the economic and financial dashboards of the Moroccan economy.

\subsection{The econometric model}

To analyze bank profitability with respect to the variables that we presented above, we adopt the linear formulation of Bourke (1989):

$$
\text { Profitability }_{i, t}=\alpha+\beta k X_{i, t}+\beta c X_{t}+\varepsilon_{i, t}
$$

where:

(1) Profitability $i, t$ : Profitability of bank $i$ at time $t$. It is measured by three ratios:

- $\mathrm{ROA}_{i, t}$ : return on assets of bank $i$ at time $t$.

- $\mathrm{ROE}_{i, t}$ : return on equity of bank $i$ at time $t$.

- $\mathrm{MIN}_{i, t}$ : net interest margin of bank $i$ at time $t$.

(2) $X_{i, t}$ : The internal characteristics of bank $i$ at time $t$ which are:

- $\quad t a_{i, t}$ : size of bank $i$ at time $t$.

- $\quad \operatorname{cap}_{i, t}$ : capitalization ratio of bank $i$ at time $t$.

- $\quad \operatorname{liq}_{i, t}:$ liquidity ratio of bank $i$ at time $t$.

- $\quad c m e_{i, t}$ : average operating coefficient of bank $i$ at time $t$.

- aloc $_{i, t}$ : fund allocation ratio of bank $i$ at time $t$.

(3) $X_{t}$ : measures the external variables:

- $t s b_{t}$ : size of the banking sector in year $t$.

- $c b_{t}$ : banking concentration in year $t$. 
JBSED

1,1

- $\quad t i b_{t}$ : interbank rate in year $t$.

- $g d p_{t}$ : economic growth rate in year $t$.

- inf: rate of inflation in year $t$.

The present formulation remains general to the design of our study, because it includes the explanation of bank profitability both as a function of three categories of determinants, the first category includes the internal variables of the bank and on which the latter can act., such (size, capitalization ratio, liquidity ratio, fund allocation ratio, and average cost / income ratio), the second category includes variables related to the banking system as a whole such (size the banking sector, banking concentration, and the interbank rate), the last category includes macroeconomic variables (GDP and inflation), formally:

$$
\text { Profitability }=f(\mathrm{BV}, \mathrm{VBS}, \mathrm{MV})
$$

where BV indicates the bank variables, VBS indicates the variables of the banking sector and MV indicates the macroeconomic variables.

For this, we point out that for each of the measures of bank profitability (ROA, ROE and MIN), we carried out three multiple linear regressions. Indeed, based on research already published, such as Naceur and Omran, 2010, we prefer to diversify the number of variables in these regressions, to obtain more convincing results. We therefore opted for three types of regression: (1), (2) and (3).

(1) Model (1) takes account of bank variables.

(2) Model (2) considers, in addition to the banking variables, the variables of the banking sector.

(3) The model (3) considers all our variables BV, VBS, and MV.

\section{Data}

The database on which we relied to perform this empirical analysis is built from different data sources. The data relating to the internal characteristics of banking establishments come from the annual activity reports of the banks studied and for the period from 1997 to 2018, these reports can be downloaded from the websites of the six banks in the sample. on the annual banking supervision reports published annually by Bank Al Maghrib, for data relating to macroeconomic variables, reference was made to the Moroccan economic and financial dashboards, the site of the High Commission for Planning, and the World Bank's sites. It is from these different sources that we drew the data necessary to conduct our analysis.

According to Table 1, these are mainly the following statistics: simple means, medians, standard deviations, maximums, and minimums. The analysis of these data allowed us to highlight the following findings: The three profitability ratios of Moroccan banks reached high values during the period covered by our study. The ROA ratio varied from $0.1 \%$ to $3.41 \%$ with an average of 1.04 , it remains the same for the ROE which also varied from $4.70 \%$ to $28.30 \%$ with an average of 12.2316 , while the MIN for its role varied from $2.60 \%$ to $7.59 \%$ with an average of 4.429 .

For the size of the banks indicated by the total assets there is a strong variation, while the Moroccan banks have considerably increased their sizes during the years of our study, the minimum size is that observed in the first year of our 1997 study with a total assets of 14.023 billion $\mathrm{DH}$ (the total assets of the $\mathrm{CIH}$ for 1997), but the banks in our sample start to increase their size year by year, the maximum size is that observed for AWB for 2015 with a total assets of 411.1 billion $\mathrm{DH}$. 


\begin{tabular}{|c|c|c|c|c|c|c|}
\hline Variables & Mean & Median & Std. Dev & Maximum & Minimum & Pert \\
\hline ROA & 1.045 & 1.040 & 0.460 & 3.410 & 0.100 & nk \\
\hline ROE & 12.321 & 11.290 & 4.545 & 28.300 & 4.700 & \\
\hline MIN & 4.429 & 4.300 & 0.828 & 7.590 & 2.600 & \\
\hline Total assets & 97.875 & 96.200 & 31.001 & 411.100 & 14.023 & \\
\hline Capitalization ratio & 9.745912 & 10.015 & 2.086 & 13.760 & 5.470 & \\
\hline Liquidity ratio & 69.900 & 71.990 & 12.612 & 92.600 & 20.930 & 109 \\
\hline Average operating coefficient & 50.795 & 48.915 & 7.606 & 67.890 & 39.000 & \\
\hline Fund allocation ratio & 97.015 & 87.100 & 30.967 & 183.500 & 38.600 & \\
\hline SB size & 622.334 & 618.400 & 44.500 & 1172.500 & 197.210 & \\
\hline Interbank rate & 3.395 & 3.220 & 0.691 & 4.600 & 2.390 & \\
\hline Banking concentration ratio & 79.632 & 80.800 & 4.735 & 86.930 & 72.310 & \\
\hline GDP & 3.847 & 4.400 & 2.939 & 7.800 & -4.000 & \\
\hline Inflation & 1.521 & 1.200 & 0.955 & 3.700 & 0.400 & Descriptive statistics \\
\hline
\end{tabular}

For ratios: capitalization, liquidity, fund allocation, and average cost / income ratio also tended to increase with relatively different averages; The size of the Moroccan banking system has also tended to increase as banks increase in size; The interbank rate and banking concentration experienced less variation during the years of the study, with averages respectively: 3.39 and 79.63. For the macroeconomic variables GDP and inflation, they experienced significant variation, for GDP, it varied between $-4 \%$ and $7.8 \%$, with an average of 3.84, and for inflation, it varied between $0.4 \%$ and $3.70 \%$ with an average of 1.52 .

\section{Model estimation}

Although it is a parsimonious model in the case of regression by the Ordinary Least Squares (OLS) method, estimation by this method neglects all kinds of heterogeneity and assumes uniformity behavior and homogeneity of observations. In addition, the data from this analysis are presented in the form of a balanced panel which has the following advantages: the inclusion of unobservable characteristics, the reduced risk of multi-collinearity, and the reduction in the estimation bias of the coefficients.

For these reasons, we have used other methods which are intended for panel data, and which take individual effects into account. There are two common assumptions made about the individual specific effect, the assumption of random effects and the fixed effects assumption. The random effects assumption (made in a random effect model) is that individual specific effects are not correlated with explanatory variables. The fixed effect assumption is that the individual specific effect correlates with the explanatory variables. If the random effects hypothesis holds, the random effects model is more efficient than the fixed effects model. However, if this assumption does not hold, the random effects model is not compatible.

And for the specification of the model to be chosen between the fixed effect model and the random effect model, the Hausman test was carried out, for which the hypothesis tested concerns the correlation of individual effects and explanatory variables. Under Ho, the model can be specified with individual random effects. If this assumption is rejected, then the model is specified with fixed individual effects.

Immediately after constitution of the database on endogenous and exogenous variables over a period of 18 years, we estimated the parameters of formulation (1) using the two methods to involve the Hausman test which allowed us to conclude that the fixed-effect model is the most relevant for our analysis. 
JBSED 1,1

110

\section{Results}

In what follows, we will present the results of the econometric estimates as well as their interpretations. We recall that for each of our endogenous variables we carried out three types of regressions, model 1 with only bank variables, model 2 with bank variables and those of the banking system, and model 3 with all our variables. The results of the regressions with the fixed-effect model provided by E-Views are presented in the following three Tables $2-4$.

The results of econometric estimates with the fixed-effect model are presented in Tables 2-4. Fisher's test indicates that the models, for the 3 cases of explained variables (ROA, ROE, MIN), are globally significant up to the $1 \%$ threshold. The quality of the fit is relatively acceptable (the adjusted $R^{2}$ is between 0.343 and 0.643 ).

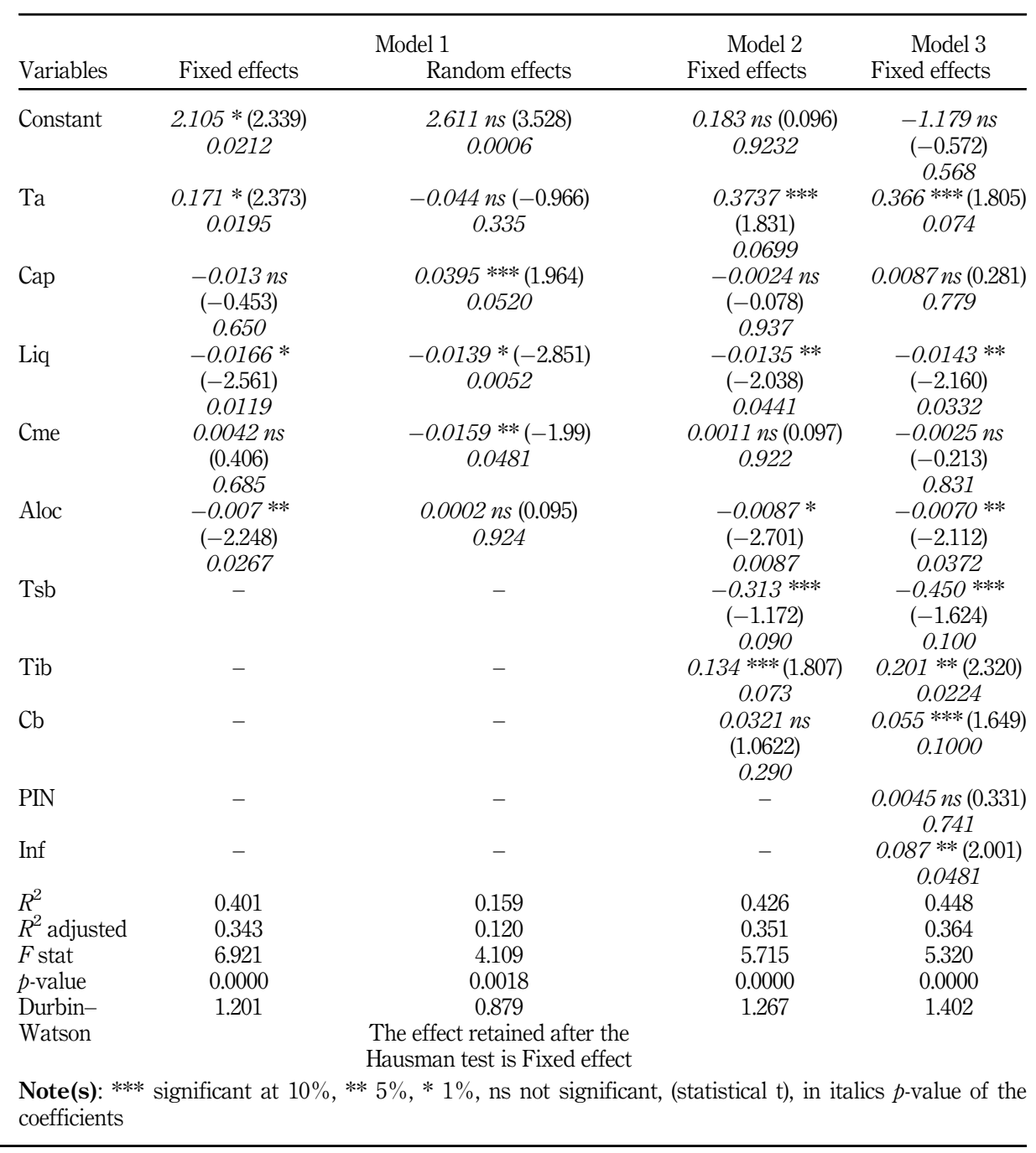

Table 2.

Estimation results of ROA 


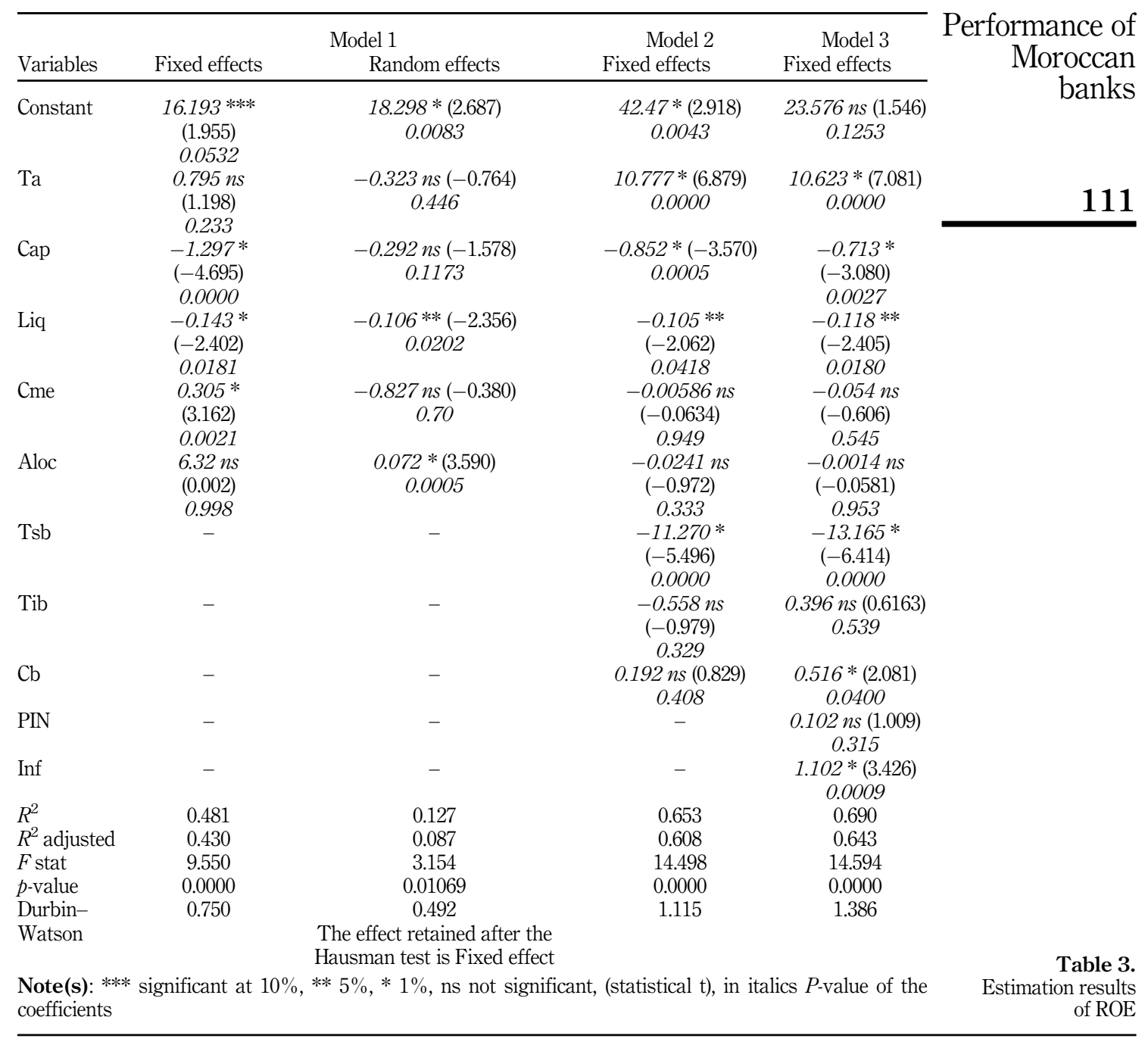

We first begin by interpreting the results of Table 2 . With the three models, we first tested the involvement of bank variables only, then we also involved the variables of the banking system, and finally we involved macroeconomic variables, the models are generally significant. at the $1 \%$ threshold, with an adjusted $R^{2}$ lying between 0.343 and 0.364 . The signs associated with the significant coefficients in the three cases are the same, the difference consists only in the significance threshold of each coefficient.

We also see that the size variable in the three models acts positively at the $1 \%$ threshold (for model 1) and at the $10 \%$ threshold (for models 2 and 3 ) with the return on ROA assets, this result can be explained by the fact that Moroccan banks have not yet reached the critical size which can harm their profitability. Indeed, some studies have shown that small banks benefit from economies of scale only when their assets exceed a specific level, and that large banks 
JBSED
1,1

\begin{tabular}{|c|c|c|c|c|}
\hline Variables & Fixed effects & $\begin{array}{l}\text { del } 1 \\
\quad \text { Random effects }\end{array}$ & $\begin{array}{c}\text { Model } 2 \\
\text { Fixed effects }\end{array}$ & $\begin{array}{r}\text { Model } 3 \\
\text { Fixed effects }\end{array}$ \\
\hline Constant & $\begin{array}{c}10.721 *(7.129) \\
0.0000\end{array}$ & $\begin{array}{c}12.916 *(10.445) \\
0.0000\end{array}$ & $\begin{array}{c}9.139 *(2.989) \\
0.0034\end{array}$ & $\begin{array}{c}10.573 *(3.139) \\
0.0022\end{array}$ \\
\hline $\mathrm{Ta}$ & $\begin{array}{c}-0.193 n s \\
(-1.605) \\
0.1115\end{array}$ & $\begin{array}{c}-0.431 *(-5.618) \\
0.0000\end{array}$ & $\begin{array}{c}-1.183 * \\
(-3.595) \\
0.0005\end{array}$ & $\begin{array}{c}-1.171 * \\
(-3.534) \\
0.0006\end{array}$ \\
\hline Cap & $\begin{array}{c}-0.054 n s \\
(-1.092) \\
0.277\end{array}$ & $\begin{array}{c}-0.076 * *(-2.270) \\
0.0272\end{array}$ & $\begin{array}{c}-0.1002 \text { ** } \\
(-1.997) \\
0.0484\end{array}$ & $\begin{array}{c}-0.1106 * * \\
(-2.162) \\
0.0330\end{array}$ \\
\hline Liq & $\begin{array}{c}-0.020 * * * \\
(-1.865) \\
0.065\end{array}$ & $\begin{array}{c}-0.028 *(-3.510) \\
0.0007\end{array}$ & $\begin{array}{c}-0.0240 * * \\
(-2.242) \\
0.0272\end{array}$ & $\begin{array}{c}-0.0230 \text { ** } \\
(-2.1194) \\
0.0366\end{array}$ \\
\hline Cme & $\begin{array}{c}-0.0565 * \\
(-3.218) \\
0.0017\end{array}$ & $\begin{array}{c}-0.0810 *(-6.075) \\
0.0000\end{array}$ & $\begin{array}{c}-0.0262 * * \\
(-1.351) \\
0.1000\end{array}$ & $\begin{array}{c}-0.0226 n s \\
(-1.146) \\
0.254\end{array}$ \\
\hline Aloc & $\begin{array}{c}-0.0069 n s \\
(-1.330) \\
0.1864\end{array}$ & $\begin{array}{c}0.0016 \text { ns }(0.446) \\
0.655\end{array}$ & $\begin{array}{c}-0.0045 n s \\
(-0.868) \\
0.387\end{array}$ & $\begin{array}{c}-0.006 n s \\
(-1.143) \\
0.255\end{array}$ \\
\hline Tsb & - & - & $\begin{array}{c}1.276 *(2.963) \\
0.0038\end{array}$ & $\begin{array}{c}1.420 *(3.132) \\
0.0023\end{array}$ \\
\hline Tib & - & - & $\begin{array}{c}0.045 n s(0.377) \\
0.706\end{array}$ & $\begin{array}{c}-0.027 n s \\
(-0.193) \\
0.847\end{array}$ \\
\hline $\mathrm{Cb}$ & - & - & $\begin{array}{c}-0.0434 n s \\
(-0.888) \\
0.376\end{array}$ & $\begin{array}{c}-1.067 n s \\
(-1.240) \\
0.217\end{array}$ \\
\hline PIN & - & - & - & $\begin{array}{c}-0.008 n s \\
(-0.361) \\
0.718\end{array}$ \\
\hline Inf & - & - & - & $\begin{array}{c}-0.082 n s \\
(-1.164) \\
0.246\end{array}$ \\
\hline$R^{2}$ & 0.484 & 0.412 & 0.539 & 0.545 \\
\hline$R^{2}$ adjusted & 0.434 & 0.384 & 0.479 & 0.476 \\
\hline$F$ stat & 9.684 & 15.13 & 9.003 & 7.845 \\
\hline$p$-value & 0.0000 & 0.0000 & 0.0000 & 0.0000 \\
\hline Durbin- & 0.9008 & 0.890 & 0.957 & 0.914 \\
\hline
\end{tabular}

Table 4.

Estimation results of NIM
The effect retained after the Hausman test is Fixed effect

\section{2}

suffer from de-economies of scale or inefficiencies of scale when their size exceeds a certain critical threshold.

The liquidity ratio acts negatively at the $1 \%$ threshold (for model 1 ), and at the $5 \%$ threshold (for models 2 and 3). We recall that this ratio is rather a measure of illiquidity. Indeed, this result is the consequence of abundant liquidity, and which entailed an additional cost for the banks. This shows that the most liquid banks hold higher levels of capital and risk. We find that this result is similar with the analysis of Molyneux and Thornton (1992) and Pasiouras and Kosmidou (2007).

But in disagreement with the result of the studies of Kosmidou et al. (2008) and Bourke (1989) who find a positive correlation between liquidity and profitability. For the fund allocation ratio, an inverse and significant correlation is detected at the $5 \%$ threshold (for 
models 1 and 3 ), and at the $1 \%$ threshold (for model 2 ) with the profitability of ROA assets. Bashir (2000) has also shown that credit policy can sometimes restrict bank profitability, when an expansionary credit policy is incompatible with the strategy pursued in terms of seeking financial resources.

For the capitalization ratio and the average cost / income ratio, we see that they have no significant impact on the profitability of ROA assets. Regarding the variables of the banking system, we find that the size of the banking system is inversely and significant correlation at the $10 \%$ threshold (for both models 2 and 3 ) with the profitability of ROA assets, this result is consistent with that of Demirguc-Kunt and Huizinga (1999), the explanation that can be attributed to this is that the larger the banking market, the greater the number of players and the harsher the competition. This competition gradually reduces the profitability of each of the players. For the interbank rate, a positive and significant correlation is detected at the $10 \%$ threshold (for model 2 ) and at the $5 \%$ threshold (for model 3 ). The banking concentration ratio is positively and significantly correlated at the $10 \%$ threshold (for model 3 ) with the profitability of ROA assets, which empirically validates the theoretical contribution of Ben Naceur (2003) and Rouabah (2006).

For macroeconomic variables, GDP has no effect on the profitability of ROA assets, while inflation has a positive and significant effect at the $5 \%$ level (model 3 ) with the profitability of ROA assets, which confirms the results of the work of Molyneux and Thornthon (1992), Guru et al. (2002), and Abreu and Mendes (2002) which shed light on the links likely to exist between return on assets and inflation.

Based on these interpretations, we then have model 3 since it has the strongest adjusted $R^{2}$ among the three, and since it accepts all these interpretations by involving all our variables.

We now turn to the interpretation of the results of Table 3 . The models are generally significant at the $1 \%$ level with goodness-of-fit (adjusted $R^{2}$ ranging between 0.430 and $0.643)$. The signs associated with the significant coefficients are the same, the difference is found just at the level of the significance threshold of each coefficient.

We note that the size variable detects a positive and significant relationship at the $1 \%$ threshold (for models 2 and 3 ) with the return on equity, which corroborates with the results of the work cited in the interpretation of Table 2 relative to the size variable. The capitalization ratio maintains a negative and significant correlation at the $1 \%$ threshold (for the 3 models) with the return on equity, confirming that a rapid approach to the question could lead to the supposition that a high CAR ratio can lower the ROE due to two mechanisms: A high ratio means a low risk and the theory of equilibrium markets which confirms a very strong relationship between risk and profitability makes us deduce a low profitability. And an increase in this ratio can mean that the debt share decreases and therefore implies a low profit linked to the tax exemption of debt charges.

The liquidity ratio, as in the case of the profitability of assets, maintains an inverse and significant relationship at the $1 \%$ threshold (for model 1 ) and at the $5 \%$ threshold (for models 2 and 3), we can advance there the same explanations relating to the liquidity ratio for the case of the ROA.

The average cost / income ratio detected a positive and significant relationship at the $1 \%$ level only at the model 1 level. While the fund allocation ratio detected no effect.

Regarding the size of the banking system, we see a negative and significant relationship at the $1 \%$ threshold (for the two models 2 and 3), which can also admit the explanations of the ROA case relative to the size of the banking system. The interbank rate had no effect, banking concentration maintained a positive and significant relationship at the $5 \%$ level (at the level of model 3).

Relative to macroeconomic variables, GDP has no significant effect on ROE, while inflation has detected a positive and significant correlation at the $1 \%$ level. Based on these 
JBSED 1,1 interpretations, we then have model 3 since it has the strongest adjusted $R^{2}$ among the three (0.643), and since it accepts all these interpretations by involving all of our variables.

We end this part of interpreting the results by interpreting the results of Table 4 . The goodness of fit is generally acceptable and significant at the $1 \%$ level, with an adjusted $R^{2}$ ranging between 0.434 and 0.476 . We also note for the case of MIN that the signs associated with the significant coefficients in the three models are the same.

Different from the previous interpretations, we find that this time the size of the bank maintains a negative and significant correlation at the $1 \%$ threshold (for models 2 and 3 ), with the interest margin, this result is confirmed by the fact that the authors argue that size can result from an aggressive growth strategy, released at the expense of margins and profitability.

The capitalization and liquidity ratios maintain a negative and significant relationship at the $5 \%$ level (at the level of the three models) with the MIN. The average cost-to-income ratio showed a negative and significant relationship at the 1\% threshold (at the level of model 1) and at the $5 \%$ threshold (at the level of model 2 ). While the fund allocation ratio did not detect any significant relationship.

Only the size of the banking system between the variables of the banking system which detected a positive and significant correlation at the $1 \%$ threshold (at the level of the two models 2 and 3 ) with the MIN. This can accept the arguments advanced for the interpretations of the ROA and ROE.

None of our macroeconomic variables detected a significant correlation with MIN. For the case of the MIN models, it is proposed to have model 2, based on the advanced interpretations, and given that it has the strongest adjusted $R^{2}$ among the three (0.479).

\section{Conclusion}

Analysis of the estimation results shows that the effects of the various explanatory variables are generally significant on the three profitability indicators ROA, ROE, and MIN. This eventually indicates that the variables involved effectively contribute to the explanation of bank profitability for the case of Morocco.

In detail, an analysis of the empirical results of our study shows that bank variables have their strong share of explaining bank profitability compared to other variables. Our results show that Moroccan banks are acting on their size in order to boost their performance, which further explains the continued expansion of the networks of Moroccan banks, and which further confirms that the latter have not yet reached a level of size which will be detrimental to their profitability even if a negative correlation between the size variable and the profitability measured by the MIN is detected during our study, which means that the large Moroccan banks do not follow the concept of economy of scale.

However, even if loans exert a motivating effect on bank income, it is observed that the levels of liquidity ratios are high and for most banks exceed the threshold of $100 \%$. This excess liquidity shows that banks maintain certain rigid taxes on the conditions for granting loans and mobilizing savings, fearing that they will not be able to cope with surprised and unforeseen risks and requests for repayment of funds.

With regard to the variables of the banking system, the size of the banking system is against the bank profitability measured by the ROA and the ROE, while it is in favor of the profitability measured by the MIN, and concerning concentration banking, we have a positive effect on the ROA and the ROE, as long as it has no significant effect on the profitability of the banks in our sample, the interbank rate for its role, has marked its positive effect on the profitability only among the three profitability indicators for the banks studied.

And with respect to macroeconomic determinants, our results are aware of the results of the empirical study by Ben Naceur (2003), and state that the effects of the variation in the level of economic growth as well as the evolution of the level of inflation are not significant. It 
should then be concluded that these two variables do not contribute to the explanation of the profitability of Moroccan banks, which means that the latter do not benefit from the dynamics of economic activity and the improvement in the economic performance of the country, or an inflationary environment.

Although the results we arrived at in our study reflect the real image of the performance of the Moroccan banking system, their empirical validation remains conditioned by a passage on other paths of research and analysis not kept. It will therefore seem advantageous to complete our study by proceeding either to conduct a study in the broad sense of all Moroccan banks taken individually or to analyze the aggregated data of the banking system as a whole and over a longer period. In addition, we can notice that the number of variables that we have involved in our analyzes remains an insufficient number to explain the profitability of Moroccan banks, other factors, such as governance, tax system, State control, the economic and political situation, and the professional quality of the staff are also likely to explain a large part of the profitability of Moroccan banks.

\section{References}

Abreu, M. and Mendes, V. (2002), "Commercial Bank interest margins and profitability: evidence from E.U. Countries”, Unversity of Porto, Portugal, Working Paper Series, No. 245.

Athanasoglou, P., Delis, M. and Staikouras, C. (2006), "Determinants of bank profitability in the southern eastern European region", Munich Personal RePEc Archive, Working Paper, No. 10274.

Bashir, A. (2000), "Determinants of profitability and rates of return margins in Islamic banks: some evidence from the Middle East", Grambling State University Mimeo, Working Paper, No. 224, doi: 10.3366/edinburgh/9780748621002.003.0008.

Ben Naceur, S. (2003), "The determinants of the Tunisian banking industry profitability: panel evidence 1980-2000", Paper Presented at the Proceedings of the Economic Research Forum (ERF) 10th Annual Conference, Marrakesh -Morocco, December.

Berger, A. (1995), "The profit-structure relationship in banking: tests of market-power and efficientstructure hypotheses", Journal of Money, Credit, and Banking, Vol. 27 No. 2, pp. 404-431.

Bourke, P. (1989), "Concentration and other determinants of bank profitability in Europe, North America and Australia”, Journal of Banking and Finance, Vol. 13 No. 1, pp. 65-79.

De Jonghe, O. (2010), "Back to the basics in banking? A micro-analysis of banking system stability", Journal of Financial Intermediation, Vol. 19, pp. 387-417.

Demirguc-Kunt, A. and Huizinga, H. (1999), "Determinants of commercial bank interest margins and profitability: some international evidence", World Bank Economic Review, Vol. 13 No. n 2 , pp. 379-408.

Demirgüç-Kunt, A. and Huizinga, H. (2000), "Financial structure and bank profitability", Policy Research Working Paper; No. 2430, World Bank, Washington, DC, (C) World Bank, available at: https://openknowledge.worldbank.org/handle/10986/21368

Dietrich, A. and Wanzenried, G. (2011), "Determinants of bank profitability before and during the crisis: evidence from Switzerland", Journal of International Financial Markets, Institutions and Money, Vol. 21 No. 3, pp. 307-327, doi: 10.1016/j.intfin.2010.11.002.

Echekoba, F., Ananwude, A. and Lateef, O. (2018), "Effect of monetary policy on the performance of the Nigerian capital market (1986 - 2016): stylized facts from ARDL Approach", Advances in Research, Vol. 14 No. 6, pp. 1-15.

García-Herrero, A., Gavilá, S. and Santabárbara, D. (2009), "What explains the low profitability of Chinese banks?", Journal of Banking and Finance, Vol. 33 No. 11, pp. 2080-2092.

Ghouila, L. and Jilani, F. (2019), "Impact des activités bancaires non traditionnelles sur l'efficience: cas des banques commerciales algériennes", Revue du contrôle, de la comptabilité et de l'audit, Numéro 9 : Décembre 2019, Vol. 4 No. 3, pp. 78-107. 
JBSED

1,1

Goddard, J., Molyneux, P. and Wilson, J.O.S. (2004), "The profitability of European banks: a crosssectional and dynamic panel analysis", The Manchester School, Vol. 72, pp. 363-81.

Golin, J. (2001), The Bank Credit Analysis Handbook: A Guide for Analysts, Bankers and Investors, 2nd ed., John Wiley and Sons, NJ.

Guru, B., Staunton, J. and Balashanmugam, B. (2002), "Determinants of commercial bank profitability in Malaysia", Paper Presented at the 12th Annual Australian Finance and Banking Conference, Sydney, 16-17 December 2002.

Kosmidou, K., Tanna, S. and Pasiouras, F. (2008), "Determinants of profitability of domestic UK commercial banks: panel evidence from the period 1995-2002, Economics, finance and accounting applied research", Working Paper Series No. RP08-4, Coventry University, Coventry, available at: http://wwwm.coventry.ac.uk/bes/cubs/aboutthebusinessschool/ Economicsfinanceandaccounting/Pages/AppliedResearchWorkingPapers.aspx.

Lanotta, G., Nocera, G. and Sironi, A. (2007), "Ownership structure, risk and performance in the European banking industry”, Journal of Banking and Finance, Vol. 31 No. 2, pp. 2127-2149, doi: 10.1016/j.jbankfin.2006.07.013.

Lawal, A., Somoye, R., Babajide, A. and IkechukwuNwanji, T. (2018), "The effect of fiscal and monetary policies interaction on stock market performance: evidence from Nigeria”, Future Business Journal, Vol. 4 No. 2, pp. 16-33.

Levine, R. (1996), "Financial development and economic growth", Journal of Financial Economics, Vol. 97, pp. 331-78.

Liu, H. and Wilson, J.O.S. (2010), "The profitability of banks in Japan”, Applied Financial Economics, Vol. 20 No. 24, pp. 1851-1866.

Mansouri, B. and Afroukh, S. (2006), La rentabilité des Banques et ses Déterminants, cas du Maroc, Université Cadi Ayyad Marrakech, Maroc, Working Paper, No. 462.

Molyneux, P. and Thornton, J. (1992), "Determinants of European bank profitability: a note", Journal of Banking and Finance, Vol. 16 No. 6, pp. 1173-1178.

Naceur, S. and Goaied, M. (2001), "The determinants of the Tunisian deposit banks' performance", Applied Financial Economics, Vol. 11 No. 3, pp. 317-319.

Naceur, S. and Omran, M. (2010), "The effects of bank regulations, competition, and financial reforms on banks' performance", Emerging Markets Review, Vol. 12 No. 1, pp. 1-20, doi: 10.1016/j. ememar.2010.08.002.

Panigrahi, A., Karwa, P. and Joshi, P. (2019), "Impact of macroeconomic variables on the performance of mutual funds: a selective study", Economic Policy and Research, Vol. 15 No. 1, p. 29.

Pasiouras, F. and Kosmidou, K. (2007), "Factors influencing the profitability of domestic and foreign commercial banks in the European Union", Research in International Business and Finance, Vol. 21 No. 2, pp. 222-237, doi: 10.1016/j.ribaf.2006.03.007.

Qureshi, F., Kutan, A.M., Ghafoor, A., Khan, H.H. and Qureshi, Z. (2019), "Dynamics of mutual funds and stock markets in Asian developing economies", Journal of Asian Economics, Vol. 65, pp. 101-135.

Rouabah, A. (2006), "La sensibilite de l'activite bancaire aux chocs macro-economiques: une analyse en panel sur des donnees de banques de Luxembourg 1994-2005”, Central Bank of Luxembourg, Working Paper, No. 21.

\section{Further reading}

Iannota, G., Nocera, G. and Sironi, A. (2007), "Ownership structure, risk and performance in the European banking Industry", Journal of Banking and Finance, Vol. 31 No. 7, pp. 2127-2149, juillet. 
Kasman, A. (2010), "Consolidation and Commercial bank net interest margins: evidence from the old and new European Union members and candidate countries", Economic Modeling, Vol. 27, pp. 648-655.

Naceur, S. and Kandil, M. (2009), "The impact of capital requirements on banks' cost of intermediation

Performance of and performance: the case of Egypt", Journal of Economics and Business, Vol. 61, pp. 70-89.

Moroccan

banks

Corresponding author

Abdelkader Derbali can be contacted at: aderbalicctu@gmail.com

For instructions on how to order reprints of this article, please visit our website:

www.emeraldgrouppublishing.com/licensing/reprints.htm

Or contact us for further details: permissions@emeraldinsight.com 